\title{
THE ROAD TO DOTCALM IN EDUCATION
}

\author{
Mark David Milliron \\ President and CEO of League for Innovation in the Community College \\ 4505 East Chandler Boulevard \\ Suite 250 \\ Phoenix, AZ 85048 \\ Phone: (480) 705-8200; Fax (480) 705-8201
}

\begin{abstract}
The DotCom era has educators running faster and faster to keep up with technology that feels more and more elusive. This paper recognizes this chase for what it is - educationally hazardous - and suggests that if we continue racing ahead, we are at risk for personal and professional crashes. Based on the work of the League for Innovation in the Community College with hundreds of colleges through conferences and consultations, this paper shares individual, organizational, and societal road hazards that have proven challenging on this road. The paper concludes with a vision of a journey toward DotCalm, with a focus on learning and inclusiveness in our technology and education adventures.
\end{abstract}

\section{KEY WORDS}

Transparent technology, return on investment, customer relationship management, digital democracy

\section{IT FEELS LIKE WE'RE MOVING TOO FAST}

I have been a part of more than 200 campus visits, conference presentations, or corporate workshops over the last five years and the feedback from very thoughtful educators and a host of other professionals almost always includes this comment. And there's a reason for the feeling. In The Innovator's Dilemma, Christensen [1] makes the powerful point that our society is experiencing the fastest adoption of a disruptive technology in human history. Industrial societies had anywhere from 20 to 50 years before disruptive innovations like electricity, automobiles, and televisions hit mass use (defined as 25 percent adoption) and drastically changed their work, play, and learning. Our information-age society, however, had little more than four years to adjust to the World Wide Web's move to mass use; we are only now beginning to arise after being digitally swept off our feet.

A useful image to put this challenge in context comes from modern Buddhist thinkers and practicing psychologists. Monks and therapists alike talk about the need to use meditation or other mindfulness techniques to slow ourselves down from our busy lives. In essence, we need to stop the car, take a deep breath, and metaphorically clean our windshields before we continue on the road ahead. Many, however, just keep speeding along. As they race ahead, they become less capable of making thoughtful choices about future directions because as the daily grime and grit builds up, they lose sight of what's right in front of them. In extreme cases, some end up in painful personal and professional crashes.

While individual differences abound regarding the need for and value of different meditative or relaxation techniques, there is little doubt that many of us are only just getting our bearings after what felt like a ridiculous joyride over the last six years. It was a raucous race on the fledgling Information Superhighway, with our organizational cars full of folks intoxicated with what Allen Greenspan called 
"irrational exuberance." And, after the broader society's dotcom crash, it seems our collective motors are only just beginning to hum again. As this journey continues, the call comes again for us to examine both our direction and who will be included on the trip.

In the books Access in the Information Age: Community Colleges Bridging the Digital Divide [2] and From Digital Divide to Digital Democracy [3] a League for Innovation in the Community College team took pains to outline key trends and provide convincing data about our need to include all students in our technology-fueled journey down the road ahead. They spent a good deal of time featuring model programs from educational institutions far and wide, showcasing leaders, teachers, and learners taking on this challenge. Building on this work, and in an effort to complement the compelling profiles of community college programs nationwide, I'd like to sound a call. It is a call for us all to commit not only to increasing the likelihood of digital inclusion in our rush to infuse technology in general and asynchronous learning in particular into education, but to something even more fundamental - facilitating the underpinnings of Digital Democracy. In the pages that follow I'll sound this call by echoing the hundreds of educators who have counseled caution for those still excited about the road ahead. In short, they urge us to clean the windshield and keep our eyes open for a host of hazards. And in an effort to make these hazards even plainer, the tone of the sections that follow will be direct and conversational.

\section{ROAD HAZARDS}

Looking for road hazards on a journey takes concentration. It's not often practiced by those with a need for speed or those caught up in their competitive drives. These folks tend to note hazards only after an accident. We want to be more thoughtful than that here, particularly with the hazards on the road ahead for education: hazards on the individual, organizational, and societal levels.

\section{A. Individual Road Hazards}

One of the most difficult individual road hazards to avoid is the tendency to fake it-to act as though we understand the technology dialogue or infrastructure just so we don't appear to be behind the times. I've been in meetings with college presidents, faculty members, student service leaders, and even chief information officers where serious faking is going on. I think we all have. People spew IT acronyms as though everyone understands them, and everyone in the room nods knowingly. I'm convinced I've been in technology-related discussions where at least three-quarters of the participants are completely lost, but for some reason we continue to blithely banter about the power of a new technology. Let's be honest: sometimes we just don't want to be the one who doesn't get it. I have to admit it: I've faked it. Have you?

We have to stop faking it. Put simply, faking it leads to tragic outcomes in education. Colleges have invested millions of dollars on vaporware systems because they were afraid of asking hard questions, not to mention their dread of the slings and arrows of being regarded as behind the times. To this day, I consider the "train is leaving the station, get on board or be left behind" rhetoric for adopting technology weak at best and frightening at worst. The fact that others are doing it or that we may be out of fashion seems a dangerously sophomoric reason to spend enormous time and money on an initiative with such broad-ranging and possibly traumatic implications. We all can advance far more compelling reasons to adopt technology, many of which are explored throughout this issue.

We view true courage in action in our techno-enamored age when we see colleagues putting their egos on the line to say, "I have no idea what we're talking about." There is power in admitting ignorance. We may not ever want or need to develop a deep understanding of every detail, but we are more likely to understand the implications of IT decisions, not to mention more likely to learn. The good news is that 
information technology hardware and software change is so rapid that we are all novices every six months; so we always have kindred spirits. The best and the brightest in technology counsel us that we all have to be ready and willing to be rookies - often - to truly make IT work for us on the road ahead. Dangerous things can happen if we let our egos get in the way of honest IT dialogue and assessment.

Closely related to the faking it phenomenon is the seduction of the new and novel. In a five-year international study of teaching-excellence-award winning faculty called Practical Magic: On the Front Lines of Teaching Excellence, participants made the cogent observation that when it comes to technology and teaching and reaching students, we have to be sure not to use technology for the novelty, but the utility [4]. This concern is real-as anyone who has suffered from a death-by-PowerPoint presentation can attest. For many of us there is a time during a presentation when, as each slide swooshes across the screen in the pitch-black room and each major point screeches to a halt, bullet by bullet, we are only moments from a primal scream and a run for the door. Sandy Shugart, President of Valencia Community College (FL), is fond of noting that "all too often, PowerPoint presentations have neither power nor a point!"

This truism came crashing home for me in the mid-1990s. I adopted presentation graphics early and used them to jazz up my talks with as many new gimmicks as I could muster. I took pride in my new acumen and worked to make my presentations jump from the screen. But one day after a presentation about student motivation, during which I had tried to catalyze a dynamic dialogue on connecting with students, I was paid a compliment. An extremely kind woman said, "That was the best PowerPoint presentation I've ever seen." It hit me like punch in the chest. In that moment I realized that as my bells and whistles melodiously ring and blow, they run the risk of muting the message that matters. I immediately became a minimalist user of presentation graphics. I still use them; however, I'm constantly working to ensure that the few slides I use supplement rather than dominate the dialogue. Moreover, I'm more interested in making my presentation a resource after the engagement than a point of attention during it - which is a clear move to a more asynchronous strategy for this tool.

It comes down to the art of what some call making technology transparent. As Michael McGrath [5] notes in his widely cited book, Product Strategy for High Technology Companies, all too often businesses are overly enamored with new technology, so much so that they actually frustrate customers and reduce profitability. For example, in the book Loyalty.com: Customer Relationship Marketing in the Age of the Internet, Newell and Rogers [6] note that a primary reason people visit websites is to get a contact phone number. Yet many businesses are so eager to force customers to use the latest and greatest Web service that they bury their phone numbers four or five links deep on the site. The result is technology that is in the way, and customers who switch to more user-friendly companies. The faculty members in the Practical Magic study were quick to note that the corollary effect can easily happen in education-new technology can get in the way of learning. The class session goes off course and becomes a journey down Tech-Support Lane as the video-data projector refuses to work; or important class sessions grind to a halt as all are encouraged to share in the glory of a slideshow that uses all the new features. Some teachers even make the unthinkingly benign but nonetheless powerfully symbolic mistake of literally turning their backs to their students as they read from the PowerPoint screen.

In a 1997 article titled "The Technology Prayers" [7], Cindy Miles and I closed with an earnest call: "Please make IT go away." It was a call for help to any higher power possible to make technology transparent, to help us transition to a time when we view the Internet and its associated technologies like electric lights or power outlets (which are amazingly complex technologies in and of themselves): simple utilities that we assume work. We were echoing the call from educators nationwide who long to be free to focus first on connecting with learners and connecting them to learning. 
A closely related roadblock builds on the intoxication with the new and novel as it makes us more effective. As individuals surrounded by technology at every turn, we are uniquely challenged to find the balance between multitasking and mindfulness. There are education articles from the 1970s rife with predictions about the rise of information technology and robotics and how these trends were going to create a new challenge for education. Because of the number of jobs lost to technology and robotics, and the increase in wealth and leisure time, education would have to create more avocational programs to help people adjust to the new lifestyle. Of course, the opposite has happened. Economists now praise the rise in worker productivity brought on by technology [8]. We now can produce more work per worker than we ever thought possible in the United States. Moreover, we take our work with us wherever we go. Our home computers are weekend workstations. Our cellphones have become constant companions as we strive to stay connected. And e-mail, the aptly named "killer application" of the Internet, has moved from unique communication form to deadly burden. We now are urged to use Blackberry devices or buy Internet phones just so we can keep up. And, worst of all, some workers have become more and more like Pavlov's dogs: at the ding of incoming e-mails they stop what they're doing, salivate, and rush to the screen. We get the proverbial nervous tic after neglecting our e-mails for 12 hours.

This technology-enabled productivity press has led to a number of challenges. I often ask groups how many of them have been busted - meaning they have been on the phone with someone they cared about deeply and have been caught typing in the background. I know I have been on both ends of that exchange; I've felt the guilt of doing it and the personal pangs of diminishment at hearing the keyboard taps in the background. This violation is exacerbated all the more by people taking cellphone calls in friend's homes, moving cars, neighborhood stores, local theatres, and even public restrooms. And holding an office conversation with one person glued to the monitor or facilitating a meeting as participants type out emails has actually become acceptable in some circles. The wired elite are always on, always connected. But are we connecting?

In his books Connnect [9] and Human Moments [10], Dr. Edward Hallowell, a senior lecturer with Harvard Medical School and the Director of the Hallowell Center for Cognitive and Emotional Health in Concord (MA), talks about the irony of how many electronic connections we have today, yet how hard it is for us to form authentic and deep personal connections with our family members and friends. In his therapy practice he sees severe dysfunction from this lack of connection-people in real pain because they feel their relationship span is "a mile wide and an inch deep." In The Lexus and the Olive Tree, Thomas Friedman builds on this point by noting that many Americans are more connected to national and global communities - through constant watching of CNN, MSNBC, and other news channels - than they are to issues and people in their own cities or neighborhoods [11].

Is the press to move faster and to look globally rather than locally going to change any time soon? I doubt it. The question is, then, can we develop the ability to be mindful of those around us in our connected fast-paced surroundings? To successfully navigate the road ahead we must. The at-risk student, the eager learner, the colleague in need all require our focus if our work is to make a difference. To paraphrase Ghandi's admonition, we must "give the gift of being truly present" with those around us if we wish to make a difference. However, in the broad analysis, we have to give ourselves some slack before we berate ourselves too harshly. This $i s$ the fastest adoption of a disruptive technology in human history. It's not surprising that we're only beginning to develop personal and cultural norms to manage the challenges. But we cannot fail to strive to meet the need to make real connections with each other and our students, particularly with the organizational and societal road hazards in our path. 


\section{B. Organizational Road Hazards}

One of the most common organizational road hazards has little to do with technology itself; it has to do with technology's relation to change. The hazard is the cultural challenge of not engaging the reasoned center of the institution in meaningful explorations of the good and bad aspects of technology in education and society. Many college conversations on technology are dominated-as are conversations on a range of other topics - by two extreme groups. One group is of caustic cynics committed to thwarting any change initiative. Sometimes caustic cynics are once-engaged professionals who have been too often burned by strategic plan after strategic plan. Based on their experience, the best course of action is inaction. From student-centered education to writing across the curriculum to MBO to TQM, they can count the fads that have washed ashore, full of presidential sound and fury, but in the end they returned nothing to the adventurous educators and students who rode the wave. Others are wrestling with personal issues far beyond the reach of rational college-based dialogue. Their arguments are often loud and logical; but scratch the surface and the seeds of fear, pain, and trauma that have little to do with the college or any specific initiative sprout to life. While these are not the only profiles that fall into this group, they both share one of the defining characteristics of caustic cynics: an almost pathological aversion to believing.

The only group that can equal in energy the venom and vigor brought to the fore by caustic cynics as they rage against the new and novel are the true believers. These professionals "got religion" on a given topic and can not understand why their truth is not universally accepted by all. They extol the virtue of their tools, techniques, or paradigms and counter any criticism by labeling it as related to a personal fault in the person who dares to raise a question. They make bold claims that deserve detailed exploration, but are deeply uncomfortable with devil's advocates who question ridiculous bromides like "technology will transform education." True believers also fit multiple profiles, from good-hearted inexperienced change agents to easily enamored zealots. And they share one of the defining characteristics of true believers: an almost pathological passion for believing.

As Eric Hoffer, my favorite longshoreman philosopher, puts it so well: In times of drastic change, it is the learners who inherit the future. The learned usually find themselves equipped to live in a world that no longer exists.

It is in the cool, reasoned center, swimming with thoughtful critics and reasoned advocates, where learners can soak in the best ways to use technology and discover the keys to not being used by technology. Yet in many institutions, the learned loud voices of the extremes frighten the best of faculty and staff away. Talented and caring educators determine that it's not wise to invest energy and effort in dialectic dialogues dominated by dogmatic diatribes. Hunker down and do your job becomes the modus operandus. It's sad. Moreover, it's paralyzing for institutions in dire need of real conversation about how to help students learn about, with, and beyond technology.

When educators in the reasoned center rise up, however, good things can happen-especially if they respect the rights of the extremes to hold their opinions, but refuse to allow them to control the destiny of the institution. It's never easy; and it usually requires significant individual courage coupled with top administration and key faculty leadership. However, by navigating through this road hazard, the journey for the institution is much more energizing. Moreover, we model the best of inclusive and yeasty participation in organizational life for our students.

Another common organizational cultural road hazard is the search for simple answers to complex questions about technology. For example, one of the most frequent straw-man arguments advanced whenever technology and learning comes up is the famous Which is better, online learning or in-class 
learning? While it may seem an appealing contrast, it is rife with complexities that make the results of the best-designed studies almost meaningless.

All of us have worked our way through education systems and can name teachers who have changed our lives - or at least lit a fire of interest on a given topic - and others we would not wish on our worst enemy. In addition, there are teaching techniques that, applied well, engage students in powerful ways. For example collaborative learning can break through learning logjams in fields from biology to philosophy. That said, all of us can point to an experience of being in a small group exercise that was excruciatingly useless. Finally, some students have no choice about their mode of instruction. Life situation, time constraints, and learning style often dictate the way in which learning will be received. Are we really willing to shut the door to learning to anyone who is unwilling to learn as we did?

Whether it's in class or on line, quality is more likely related to who is involved in instruction (teachers and learners), the quality of the curriculum, the multiple modes of delivery, and the learning strategies engaged. Indeed, as Web learning emerged in 1996, then League for Innovation President, Terry O'Banion, made the point that while great things might be ahead; we needed to confront the reality that the Web "holds the horrible potential of making already terrible instruction that much more available." Moreover, with the ever-more-common hybrid models of delivery-including elements of in-class and online tools across classes and programs - the comparison of modes becomes even more problematic. Finally, an admonition worth noting here comes from a theme that wove its way through every stage of the Practical Magic study on teaching-excellence-award winners. Faculty in this study warned again and again to beware of anyone claiming to know the final answer: the experience of these educators show there clearly is not one best way to teach!

Yet another quest for simple answers to complex questions surrounds technology ROI: Return on Investment. As the dotcom bubble burst and businesses again accepted the longstanding importance of a little thing called profit, so too did they begin to look at their technology purchases and work to relate them directly to their bottom lines. Complex metrics that capture multiple value principles emerged, such as the Applied Information Economics, Customer Index, Balanced Scorecard, Economic Value Added, Economic Value Sourced, and Real Option Valuation have became essential parts of technology reviews.

The debate about ROI in industry is mirrored by the conflict over the creation of concrete ROI measures in education. We have a complex combination of fiscal, operational, service, and learning variables to consider with regard to technology. Does IT help us improve our bottom lines, smooth operations, expand student service, and - the Holy Grail-improve learning? The importance of these variable sets is fiercely debated as any ROI discussion emerges, a debate made even more challenging by the distinction between cognitive and discrete skill measures of learning. Moreover, there is a cost-of-entry issue regarding technology in education. Without a certain level of technology services and learning options, many students will not consider attending your institution as we boldly move into the $21^{\text {st }}$ century. In the business world it's called the pay-to-play principle.

In the end, whether it's looking for the best way to teach or not teach with IT or exploring ROI for technology in our colleges or wrestling with the ever popular techno against humanist, high-tech versus high-touch debate, we have to be willing to search for answers without jumping to simple or predisposed views. These are meaty issues not easily resolved. The answers almost always include a caveat: it depends. Therein is the major hazard. Just as we must encourage organizational conversations with an acceptance of diverse opinions, we must be comfortable with complexity in answers when we pose complex questions. Ironically, small and large scale IT initiatives can be stalled for months and years 
because of this phenomenon. Many times we are too eager to find one best way or an incontrovertible answer before we decide. This clinging to the desire for simple answers makes us eminently less able to steer clear of organizational road hazards.

The final hazard I'll mention in this section is actually inclusive of both the individual and organizational level. All too often because of fear, ignorance, or exhaustion, individuals and organizations relinquish control and let information technology happen to them. Recently I was a part of a conversation in which a highly intelligent educational professional proudly pronounced his refusal to get a cellphone. He said, "I just don't want to be answering a phone all the time, to be at the mercy of people's expectations." A caring colleague, also in the conversation, gently noted that unreasonable expectations are indeed frustrating, but that this weakness in others had not stopped her from taking the cellphone plunge. She noted, "I just had to learn that these little things have an off button. I only use it when $I$ want to. And now I just love the convenience." I wish I could have taken a picture of the proud pronouncer's face as he contemplated her response. It was as though he'd never realized you could turn cellphones off.

I had a similar epiphany when a good friend made the observation that turning off the feature in my email program that automatically checks for new messages is the ultimate cure for the Pavlovian e-mail syndrome. When retrieving new messages must be triggered manually, you suddenly gain control of when and why your messages flood into the inbox. This little change has made all the difference in the worldparticularly as I do things like write this paper. In the past, if I had my e-mail program on in the background, the tempting little sound that welcomed new messages would constantly draw me to check for office emergencies. I've taken it one step further: I've begun turning off my monitor or closing my laptop lid whenever I'm at my desk but not using the computer.

A more concrete teaching and learning example confronts me whenever I speak at a college or event. Very often, because I use technology as an element in my presentations, a technology support person is put in charge of my speaker setup. Often these professionals are incredibly accommodating; some call months in advance to prepare the setting to any specifications I desire. I love these folks. With my presentation and workshop style, their willingness to adapt makes all the difference in the world. Because I enjoy connecting with the participants in an effort to create greater energy in the room, I prefer no lecterns, a wireless lapel microphone, and a small, discreet table for my laptop placed close to the audience. I want to be able to literally reach out and touch the folks with whom I'm working. This setup just changes the dynamic, especially when we're exploring challenging topics like technology in education or strategies for reaching at-risk students.

Sometimes, though, it's impossible to make an early connection with anyone in charge of the setting. Or because we are part of a larger program, the room has been preset by the hotel or by a theater tech-support team. The corresponding awkward situations - for example being placed at the back of a deep stage behind a tall lectern facing a theater too large for the group with an angry audience sitting in the back rows struggling to see projected PowerPoint in a fully darkened room-have taught me to arrive very early to any speaking engagement. I try to be as gracious as possible, but I have learned that for the sake of the audience, I have to take as much control as possible of the learning situation and manipulate the environment. Of course, any good teacher does this on entering a classroom. I have literally marched my laptop and RGB video cable out to the middle of a theater or multipurpose room to join the faculty and staff in dialogue. But sometimes these moves challenge and threaten tech-support or logistics persons, so much so that they rebel. Sometimes they lie. I have been told with a straight face by technical people that something I knew was possible was impossible and that I'd have to do it their way. It suddenly becomes a control issue. 
It's clear to me that some educators are at the mercy of those willing to take control of technology. They suffer in classrooms and on software systems that are not designed to meet their needs or the needs of their students. Often because we don't know what is possible or even what questions to ask, we end up feeling like we are no longer using technology, but are being used by it. From annoying classroom technology configurations to multimillion-dollar ERP system choices, some essential decisions that impact the entire college community are turned over to individuals who care little about teaching or reaching students. Alan Cooper is the father of the Virtual Basic programming language and a true technology insider who wrote the book The Inmates Are Running the Asylum: Why High Tech Products Drive Us Crazy and How To Restore the Sanity [12]. In it, he observes that through no ill will or evil intent, crucial decisions in business are being driven by technologists designing software and hardware. For the most part, these professionals love technology, which is why the quest for innovative features and functions propels increasingly complex and ultimately less useful technology. He argues that, for businesses to gain better control of their journeys on the road ahead, there will have to be an emphasis on developing either more technology-savvy businesspeople or more business-savvy technologists. Of course the corollary for education is equally true; as we move along the road ahead, we can gain greater control of our learning environments by fostering and supporting the development of more technologysavvy educators and more education-savvy technologists.

This need for a sort of technology renaissance leader has made the quest for the ideal chief technology officer or chief information officer in education problematic. Do you look for someone who knows the education world, with its academic freedom, participatory decision processes, and student-centered focus, and hope that person can develop or hire subordinates with good technology skills? Or do you seek out the best technologist possible, allowing for the time it will take to learn the academic culture? As you have probably already guessed, the answer is most likely It depends.

Whoever we hire, we have to make choices. And our perspective toward these choices with regard to technology is what really counts; we have to own them and ground them in some construct or purpose. For example, colleges in the League for Innovation Vanguard Learning College program have adopted learning-centered education as their guide to technology choices [13]. Any technology tool or technique has to prove that it will ultimately improve or expand learning. While this perspective seems simplistic, when these issues are explored with honest and tough-minded debate, ever more meaningful technology choices emerge. The alternative is to turn these decisions over to someone and spread the blame. However, as the proponents of internal locus of control expound, if we choose this path and play the victim on either the individual or organizational level, we will be hard pressed to handle the stress of preparing students for an increasingly complex, connected world - a world filled with sometimes frightening societal hazards.

\section{Societal Road Hazards}

Even with the loss of more than seven trillion dollars in market capital since the dotcom crash, it is still easy to become wrapped up in the optimism and excitement that can surround technology discussions. Indeed, I am more often than not eagerly looking ahead to the world my children will experience. As natives in a digital technology world, their experiences and perspectives will be strikingly different from my own techno-immigrant viewpoint. Someday I'll be forced to confess to them that I thought Pong was an exciting video game, and that in my grade school, a rolling slide show accompanied by cassette-tape narration was a high-tech multimedia event. Not so for them. They will never know a world without computer-generated animation, Internet, e-mail, or sophisticated search engines that put information from sources across the globe at their fingertips. But they will also be challenged to avoid hazards in their youth the likes of which no generation has ever faced. 
At a conference last year, I was struck by the story of an 11-year-old boy who was at the center of a horrific child-abuse case. Earlier that month, he had chosen for a class project the topic of celebrity impersonators. He immediately jumped on the Internet and put celebrity impersonators in a search engine, and up came thousands of links. The first few were interesting. But then, quite by accident, he clicked on a hyperlink that launched him into a pornography site that seized his computer. Suddenly pop-up window after pop-up window came on the screen. The faster he closed them, the faster they appeared. He finally decided to turn off the computer in hopes of wiping the Web intruder off his desktop, but little did he know that somewhere in all the clicking and popping, the intrusive site had changed the default home page on the computer's Internet Browser to a pornography site. Later that day, his father came home, launched the browser and was also swept away in a flashflood of pop-up pornography. In his surprise and anger, the father leaped to the conclusion that his son had been cruising these sites, and he proceeded to beat the boy until he was bloody and bruised.

This example is equaled in its chilling effect only by last year's break in the Operation Candyman child pornography sting. In a March 2002 story in The New York Times, David Stout [14] reports:

A nationwide Internet child-pornography ring has been smashed with the arrest of about 90 people, including two Roman Catholic priests, a school bus driver, a teacher's aide and a police officer, federal authorities said today.

"It is clear that a new marketplace for child pornography has emerged from the dark corners of cyberspace," Attorney General John Ashcroft said at a news briefing. "Innocent boys and girls have been targeted by offenders who view them as sexual objects.". . .

One Web site advertised itself as "for people who love kids," the authorities said. The site invited people to "post any type of messages you like" and offered a postscript: "If we all work together, we will have the best group on the Net."

For the last seven years, commerce on legal adult pornography sites was the biggest moneymaker on the Net, grossing billions as the industry expanded operations on and offshore. Now, online gambling has eclipsed pornography as the largest moneymaker, and it is poised to become a global powerhouse [15]. As you likely know, both the online gambling and pornography industries invest millions in highly sophisticated technology and aggressive "sticky-marketing" strategies - techniques that aim to suck surfers in, capturing their attention, loyalty, and dollars [16].

These are the same techniques adopted by hate groups over the last decade. If you visit Tolerance.org, a website sponsored by the Southern Poverty Law Center, you can learn more about how hate groups have grown to love the Internet, leveraging its associated tools to organize and spread their venom locally, nationally, and internationally. You can literally track hate groups across the United States [17] and see graphic examples of their sticky Web strategies in action [18]. And for a final look at the face of evil online, explore the use of the Internet by international terrorists to raise money, coordinate attacks, and recruit new followers (see Newsweek's October 2001 story, “The Road to September 11"). It's clear from the reports of law enforcement agencies from the FBI [19] to Interpol [20] that international terrorists have aggressively adopted and leveraged what many in the United State see as the ultimate symbol of intellectual freedom and exchange: the Internet. 
But lest we think it's just the extremes that should concern us, let's not forget the powerful tools at the fingertips of all business, government, religious, and political organizations. Each of these sectors is urged to develop strong Customer Relationship Management (CRM) systems that track as many of our interactions as possible. Indeed, most credit card companies today employ sophisticated artificial intelligence engines capable of almost 95 percent accuracy in detecting when your card is stolen. No, they don't have cameras nationwide - that's the purview of the U.S. National Security Agency (NSA) and soon the office of Homeland Security. What the credit-card companies have is your shopping profile. If something is bought that does not fit within your standard predicted profile, the system automatically alerts the fraud department, which immediately tasks a service agent to contact you.

I was made aware of these systems a little over two years ago, after I received a cellphone call from my credit card company asking if I had lost my card. I didn't know it was lost; it must have fallen out of my PDA case only 30 minutes earlier at a local coffeehouse. I thought to myself: this major multinational company with thousands of employees and billions in assets has a system to detect irregularities in my buying behavior that is so sophisticated that it can spot possible theft of my credit card and contact me all in a 30-minute period! While I was thankful for the service, the incident did give me pause.

Churches are also beginning to expand their reach online. Major Christian denominations all have extensive websites and are piloting a range of worship services and fundraising techniques (e.g., www.baptist.org, www.unitedmethodist.org, www.presbyterianchurch.org, www.catholic.org), as are Muslims (e.g., www.muslim.org, www.islam.org), Buddhists (e.g., www.dharmanet.org, www.prajnaparamita.com), Hindus (e.g., www.hindu.org, www.hindunet.org), and Taoists (e.g., www.taoist.org, www.tao.org).

In addition to businesses and churches, on the political front we are girding for the 2004 Presidential Election, which will arguably be the most Web-focused election yet. Campaign managers are already designing detailed sites, to connect with potential voters and spread their messages far and wide. From President George Bush (http://www.whitehouse.gov/) to his potential rivals John Kerry (http://www.johnkerry.com/), Joe Lieberman (http://www.joe2004.com), and John Edwards (http://www.johnedwards2004.com/), the online race has already begun. And if businesses and governments can use artificial-intelligence engines to predict our shopping behavior or civic loyalty, how long do you think it will be before the major political parties have a comprehensive CRM system of their own to drive affiliation and fundraising. You don't need to wait at all; it's already here (http://www.politicsonline.com). A Digital Democracy indeed!

\section{TURNING TOWARD DOTCALM}

In a 2001 EDUCAUSE Review article titled "Education in a Digital Democracy," Cindy Miles and I [21] noted the Jeffersonian challenge of our time. As the champion of public education in the United States, Jefferson saw education's broadest purpose as providing the foundation for freedom and democracy. He made the bold claim that "if a society expects to be ignorant and free, it wants what never was and what never will be." This statement has never been truer than it is today; so many have information at their fingertips, yet are not sure what to do with it. Thomas Friedman makes the point well:

At its best, the Internet can educate more people faster than any media tool we've ever had. At its worst, it can make people dumber faster than any media tool we've ever had. The lie that 4,000 Jews were warned not to go into the World Trade Center on September 
11 was spread entirely over the Internet and is now thoroughly believed in the Muslim world. Because the Internet has an aura of "technology" surrounding it, the uneducated believe information from it even more. They don't realize that the Internet, at its ugliest, is just an open sewer: an electronic conduit for untreated, unfiltered information [22].

The implications of our choices with and uses of information are profound. These choices will dictate whether or not we and our students can truly live free in this increasingly connected world. Indeed, no amount of slowing down will help if we don't recognize the individual, organizational, and societal hazards, or if we aren't wise enough to understand why they're hazardous!

Therefore, as engaged educators we must continue to champion the liberal-arts underpinnings of education-communication; computation; critical thinking; problem solving; information management; interpersonal, personal, and community skills - even as we strive to include broader segments of society in the Information Age. We must strive to give our students the ability to learn, earn, and live well, and to participate as active citizens in a vibrant connected community.

Michael Novak is the George Federick Jewett Chair in Religion and Public Policy at the American Enterprise Institute for Public Policy and Research, and the author of several seminal books on life in a democracy [23]. Speaking at a recent meeting of the Business Higher Education Forum [24], Novak noted the importance of today's educational institutions' emphasizing core habits. He argued that there are core habits necessary for a democracy and a market economy to work, habits such as creativity and innovation, enterprise and effort, community involvement and care, and realism and accountability. To this list I would add courage. The courage to thoughtfully move down the road ahead, hazards and all, ever filled with the expectations of creating a better person, a better organization, and a better world.

We've gone careening down the road to DotCom and we know now where that leads. There has to be a better way. Maybe it's time to slow down, look around, and get on the road to DotCalm - a place where we can thoughtfully engage and explore all aspects of technology, good, bad, or indifferent; a place where we can move beyond love affairs with the new and novel to a passion for the essential and important; a place beyond frantic multitasking with mindful focus on the people and passions that make life worth living. And let's bring as many along with us as we can.

\section{REFERENCES}

1. Christensen, C. The Innovator's Dilemma. Cambridge, MA: Harvard Business School Press. Education in the Digital Democracy, 1997.

2. de los Santos, G., de los Santos Jr., A., and Milliron, M. Access in the Information Age: Community Colleges Bridging the Digital Divide. Mission Viejo, CA: League for Innovation in the Community College, 2001.

3. de los Santos, G., de los Santos Jr., A., and Milliron, M. From Digital Divide to Digital Democracy. Phoenix, AZ: League for Innovation in the Community College, 2003.

4. Roueche, J. E., Milliron, M. D., and Roueche, S. D. Practical Magic: On the Front Lines of Teaching Excellence. Washington, DC: American Association of Community Colleges, 2003.

5. McGrath, M. Product Strategy for High Technology Companies. New York: McGraw-Hill, 2000.

6. Newell, F., and Rogers, M. Loyalty.com: Customer Relationship Management in the New Era of Internet Marketing. New York: McGraw-Hill, 2000.

7. Milliron, M., and Miles, C. The Technology Prayers. In: From the Facilitator, League for Innovation in the Community College Technology and Learning Connections (TLC), 1998. 
8. Greenspan, A. Productivity. In Federal Reserve Board Speech, U.S. Department of Labor and American Enterprise Institute Conference. Washington DC, October 2002. http://www.federalreserve.gov/boarddocs/speeches/2002/20021023/default.htm

9. Hallowell, E. Connect. New York: Pantheon, 1999.

10. Hallowell, E. Human Moments. New York: Health Communications, 2001.

11. Friedman, T. L. The Lexus and the Olive Tree: Understanding Globalization. New York: Anchor Books, 2000.

12. Cooper, A. The Inmates are Running the Asylum: Why High Tech Products Drive Us Crazy and How to Restore the Sanity. SAMS, 1999.

13. http://www.league.org/league/projects/lcp/

14. Stout, D. Candyman Sting. The New York Times, March 19, 2002.

15. http://www.msnbc.com/news/544764.asp

16. http://www.sticky-marketing.net/

17. http://www.tolerance.org/maps/hate/

18. http://www.tolerance.org/hate internet/

19. http://www.fbi.gov/

20. http://www.interpol.int/

21. Milliron, M., and Miles, C. Education in a Digital Democracy. EDUCAUSE Review. 2001. http://www.educause.edu/pub/er/erm00/articles006/erm0064.pdf

22. Friedman, T. Global Village Idiocy and the Community College. In League for Innovation in the Community College Leadership Abstracts 15(6): 2002. http://www.league.org/publication/abstracts/leadership/labs0602.html

23. Novak, M. The Spirit of Democratic Capitalism. New York: Simon \& Schuster, 1982.

24. Novak, M. Winter Business Higher Education Forum. La Jolla, CA, February 2003.

\section{ABOUT THE AUTHOR}

Mark David Milliron is President and CEO of the League for Innovation in the Community College, an international consortium dedicated to sharing and catalyzing innovation in community colleges (www.league.org). Mark has a passion for exploring teaching excellence, student success strategies, leadership development, future trends, and the human side of technology change. He has authored books, monographs, and articles; spoken at colleges, corporations, and conferences across the country and around the world; and served as a key resource for local, state, and national government programs. He has served on the Board of the American Council on Education (ACE), is a panel member of the U.S. Department of Education's National Assessment of Vocational Education (NAVE), and sits on several other educational, non-profit, and corporate boards. He currently serves as a Distinguished Adjunct Faculty Member at the University of Texas at Austin's Graduate Program for Community College Leadership. In 1998, the University of Texas at Austin's College of Education honored Mark as a Distinguished Graduate for his service to the education field. Mark was also named one of the top Shapers of the Future by Converge Magazine in August 2000. 